\title{
"OLAHAN KAWASAN KONSERVASI" DESA WISATA JAWA (MEWUJUDKAN MASYARAKAT SADAR WISATA BERBASIS POTENSI LOKALPADA MASYARAKAT KEJI, UNGARAN BARAT)
}

\author{
Fulia Aji Gustaman, Harto Wicaksono, dan Fajar \\ Fakultas Ilmu Sosial Jurusan Sosiologi dan Antropologi UNNES
}

\begin{abstract}
Tourism event is new industrial activities that bring many economic benefits to the perpetrator and the owner of the area where the tourism activities take place, as the case that was occur in Keji Village community. Processed tourist villages based on community conservation Keji Village has a different potential with tourist activities in Indonesia. Tourism that is offered by Keji Village is a reproduction of socio-cultural and nature, combined with the needs of the tourists both local and foreign. In realizing Keji Village as a tourist center that sells the peculiarities of the village in a sustainable manner, Keji community has done a variety of strategies, including building participation of Keji Village community. Participation conducted by community still limited manipulative participation by the management. It was proven when integrating a range of potential activity and a series of typical tourist village still seem not communicated. Participation is still not reached an agreement in realizing the Keji Village as a tourist village. One of the indicators is internal conflict among the administrator, community, and art galleries in the Keji Village. Even though with the management system and marketing potential are being made to introduce to the outside world is still experiencing problems. Problems that occur because people are in a hurry to get maximum benefit economically. Such orientation makes people complacent, that in fact Keji Village community wants to offer the culture of rural communities that packed in the travel industry for the tourist.
\end{abstract}

Keywords: conservation area, tourist village, and tourism awareness 


\section{PENDAHULUAN}

Kegiatan pariwisata merupakan kegiatan industri baru yang mendatangkan banyak manfaat ekonomi bagi pelaku dan pemilik wilayah di mana tempat kegiatan pariwisata berlangsung. Banyak yang bisa dikembangkan dengan munculnya industri pariwisata, mulai mengenalkan panorama wisata alam sampai pada eksotisme budaya yang ditawarkan. Kegiatan pariwisata telah banyak melahirkan dan menstimulus munculnya industri kreatif misalnya kerajinan lokal yang bernilai ekonomi tinggi yang memanfaatkan kekayaan lokal. Bahkan kegiatan ini telah menjadi bagian dari mata pencaharian penduduk mulai dari jasa transportasi, guide, dan penjual makanan, serta kerajinan.

Peluang yang muncul atas kebutuhan rekreasi banyak menstimulus masyarakat untuk menguatkan budaya yang hampir punah untuk dilestarikan dan dikembangkan menjadi daya tarik wisata. Bagi masyarakat kegiatan wisata ini seperti satu wajah, dua karakter. Satu posisi digunakan untuk menguatkan budaya lokal, pada satu posisi penguatan budaya bisa dikemas menjadi produk kegiatan wisata yang banyak mendatangkan keuntungan ekonomi. Fenomena ini bahkan pernah terjadi pada industri pariwisata di Bali. Tidak hanya pada masyarakat Bali, virus $\mathrm{N}^{\prime}$ Anch juga telah menular pada masyarakat di luar Bali untuk mengembangkan daerahnya menjadi wisata yang tidak kalah menarik dengan Bali. Salah satu daerah di Kabupaten semarang yang mulai mengadopsi pengembangan wisata Bali, yaitu Desa Keji.

\section{HASIL DAN PEMBAHASAN}

\section{Potensi Desa Keji sebagai Desa Wisata Berbasis Kultur Jawa}

Potensi Permainan Tradisional

Permainan Tradisional Dakon

Permainan dakon sudah diwariskan secara turun-temurun oleh masyarakat desa keji. hingga saat ini permainan dakon ini masih terus dilestarikan oleh masyarakat desa keji, utamanya adalah anak-anak. Permainan dakon adalah permainan sederhana yang mengasah daya nalar anak. Pada umumnya papan dakon terbuat dari kayu dan plastik yang dihias sedemikian rupa sehingga tampak menarik.

Sebagai isian disetiap lobang biasanya menggunkan cangkang kerang yang digunakan sebagai biji dakon. Ada 14 (empat belas) lubang dan 2 (dua) lubang besar di pucuk kanan dan kiri yang dibuat dalam papan permainan dakon ini.

Permainan dakon hanya bisa dimainkan oleh 2 (dua) orang. Permainan dianggap selesai apabila salah satu pemain sudah tidak ada biji lagi yang dapat diambil (seluruh biji ada di lobang besar disisi kanan dan kiri pemain). Pemenang ditentukan dengan yang mendapatkan biji terbanyak.

\section{Permainan Tradisional Egrang}

Permainantradisional egrang terbuat dari bambu yang di konsep sedemikian rupa sehingga bisa di jadikan sebagai permainan anak-anak. Dalam memainkan egrang dibuthkan ketrampilan khusus dan keseimbangan tubuh, sehingga tidak semua orang bisa melakukan permainan tradisional ini.Anak-anak di desa keji hingga saat ini masih mengembangkan permainan tradisional ini. Tak jarang permainan ini juga ikut dimainkan dalam acara-acara tertentu, seperti diselipkan disela-sela pementasan jaran debog. 


\section{Potensi Kuliner}

\section{Gethuk Tetek Melek}

Gethuk tetek melek adalah makanan tradisional khas desa keji, makanan yang berbahan baku singkong ini hampir sama dengan kue jongkong. Bedanya Cuma pembungkusnya saja. Kalau jongkong dibungkus dengan daun pisang, sedangkan tetek melek dibungkus plastik. Cara membuatnya mudah. Singkong cukup diparut dan diberi garam dan gula jawa selanjutnya dikukus dan diletakkan di atas nampan. Tunggu sampai dingin baru dipotong-potong dan disajikan dengan parutan kelapa. Dinamakan Tetek Melek karena pembuatannya sambil melek-melek (begadang) dengan harapan yang menyantap gethuk ini bisa terus melek (terjaga) dalam menyaksikan pertunjukan adat dan tarian.

Pecel Gablok

Pecel gablok juga salah satu makanan khas yang berasal dari desa keji, pembuatan makanan ini menggunakan bahan baku dari ketan yang di padatkan yang oleh masyarakat desa keji dinamakan geblog. Tidak ada bumbu khusus yang digunakan dalam pembuatan geblok cukup ketan dan sedikit garam saja kemudian dibungkus plastik dan direbus.Sebagai mana pecel pada umumnya bumbu yang digunakan pada pecel gablokadalah bumbu kacang dan sayuran yang melengkapi biasanya kangkung, bayam atau kecambah di tambah irisan mendoan.

Pecel gablok dan gethuk tetek melek merupakan makanan khas masyarakat desa keji. Makanan tradisional tersebut sering disajikan saat wisatawan datang sebagai bagian dari welcome drink. Keduanya adalah makanan sehari-hari masyarakat Dusun Suruhan, yang masih ada dan sering dikonsumsi masyarakat sampai saat ini.Menurut masyarakat setempat penggunaan singkong dan ketan bagi masyarakat Dusun Suruhan adalah solusi karena jumlah padi yang kurang memadai saat itu.

\section{Potensi Alam dan Homestay}

Desa yang terletak di Lereng Gunung Ungaran ini dikenal sebagai sebuah desa yang memiliki panorama alam yang sangat indah.Posisi Desa Keji yang berada di ketinggian350-430 $\mathrm{m}$ dari permukaan air laut menjadikan desa ini memiliki udara yang sangat sejuk dengan suhu udara rata-rata sekitar 29 derajat Celcius.Hamparan kebun yang ditumbuhi lebatnya pepohonan serta sumber air watu Kemloso yangairnya sangat jernih menjadi pemandangan yang sangat menakjubkan untuk dinikmati bagi wisatawan yang berkunjung kesana.

Sebagai sebuah destinasi pariwisata Desa Keji telah dilengkapi dengan fasilitas homestay atau menginap di rumah warga, dengan ketentuan satu rumah ditempati 2-3 wisatawan dan membayar uang menginap sebesar Rp 50.000,00. Pembagian homestay dilakukan oleh panitia penyelenggara wisata. Wisatawan yang menginap di desa tersebut akan dipisah sesuai dengan jenis kelamin. Panitia penyelenggara merupakan pengawas kegiatan wisatawan yaitu kepala Dusun dan sesepuh desa.

\section{Potensi Seni Tradisional}

Tarian Kuda Lumping

Salah satu kesenian tradisional yang ada di Desa Keji adalah Kesenian Kuda Lumping, kesenian ini awal mulanya dibawa oleh dibawa oleh salah satu tokoh masyarakat yaitu Mbah Rajak Suharto. Mbah Rajak Suharto sendiri merupakan sesepuh di Desa Keji, dahulu beliau belajar tari dengan seniman yang berasal dari 
ambarawa yaitu Pak Jumadi yang sekaligus sebagai instruktur tari pertama di Dusun Suruhan Desa Keji.

Selanjutnya ada tahun 1971 dibentuk paguyuban Langen Budi Utama yang menaungi kesenian Kuda Lumping se-kabupaten Semarang. Kuda Lumping di Dusun Suruhan, Desa Keji ini dijadikan sebagai contoh kesenian Kuda Lumping tingkat Kabupaten Semarang.Pewaris Kuda Lumping saat ini sudah ada 3 generasi, bentuk kesenian yang sudah melekat dengan Dusun Suruhan, Desa Keji menggambarkan pengetahuan masyarakat tentang kesenian secara turun-temurun dari generasi ke generasi yang terus dikembangkan dan dilestarikan hingga sekarang.

\section{Tarian Kuda Debog}

Tari Kuda Debog merupakan tarian kreasi atau ciptaan baru dari hasil inovasi. Tari Kuda Debog mengadaptasi dari tarian Kuda Lumping yang sudah ada di Dusun Suruhan. Perbedaan tari Kuda Debog dengan tari Kuda Lumping antara lain terletak pada pemain, kostum dan musik. Penari Kuda Debog umumnya berusia 8-12 tahun, sementara penari Kuda Lumping berusia 17-45 tahun. Tari Kuda Debog disempurnakan oleh Bapak Rajak dengan mengadaptasi gerakan Kuda Lumping.

Pakaian yang digunakan saat pentas tari Kuda Debog adalah celana hitam yang dilapisi daun pisang dengan kuda yang terbuat dari pelepah pisang (dalam bahasa setempat debog), untuk pakaian tari Kuda Lumping menggunakan celana kain hitam dan kain batik (jarik). Musik untuk tari Kuda Debog lebih ke arah tembang dolanan, seperti Prau Layar sementara untuk musik tari Kuda Lumping sesuai dengan aturan Kuda Lumping lainnya.Bapak Rajak secara khusus membuatkan tembang untuk tari Kuda Debog.

\section{Potensi Kebudayaan}

Masyarakat Desa Keji kususnya masyarakat Dusun Suruhan masih menjalankan Ritual Merti Dusun dan Ritual Iriban Banyu. Keberlangsungan ritual tersebut adalah keyakinan masyarakat mengenai wujud rasa syukur masyarakat atas berlimpahnya rejeki yang diberikan oleh Sang Pencipta. Ritual yang diadakan sebagai penghormatan kepada leluhur Dusun Suruhan yaitu Mbah Buyut Benah atau Mbah Klemu yang sering disebut sebagai danyang Dusun Suruhan.

\section{Ritual Iriban Banyu Kemloso}

Sumber air watu Kemloso yang tak jauh dari lokasi tersebut juga jadi perlengkapan perwisataan. Lebih-lebih setiap tahunnya ada ritual Iriban Banyu kemloso.Perayaan yang jatuh pada Agustus tepatnya Sabtu pahing biasanya di gelar besar-besaran dengan kirab sesaji ke sumber air pengidupan warga itu.

Sebelum acara ritual, lokasi sekitar sumber akan dibersihkan terlebih dahulu. Ritual Iriban Banyu hanya dilakukan oleh kaum laki-laki, kegiatan dalam ritual ini yaitu dengan membersihkan sumber mata air Watu Kemloso dilanjutkan dengan makan bersama.Menurut masyarakat setempat ritual Iriban Banyu kemloso sebagai upaya ungkapan rasa syukur warga sekaligus upaya pelestarian sumber air.

\section{Ritual Merti Dusun}

Kegiatan dalam Ritual Merti Dusun antara lain dimulai dengan pawai atau kirab membawa tumpeng yang berisi hasil kebun, makanan tradisional, buah-buahan. 
Warga mengenakan busana daerah yaitu batik dan kebaya. Ritual Merti Dusun dimulai dari sebuah lapangan yang berada di Dusun Suruhan selanjutnya rombongan berjalan menuju rumah Pak Bayan, dilanjutkan makan bersama dan pada malam hari diadakan acara wayang kulit. Pertunjukan wayang kulit adalah hiburan utama dalam Ritual Merti Dusun. Pertunjukan wayang kulit dapat diganti dengan pertunjukan Kuda Lumping.

\section{Sejarah Terbentuknya Wisata Desa Keji}

Desa Kejiterletak diKecamatan Ungaran Barat, Kabupaten Semarang. Desa Keji ini memiliki banyak potensi baik berupa alam maupun budaya. Letak Desa Keji yang berada di lereng Gunung Ungaran memberikan kekhasan suasana pedesaan. Panorama perbukitan, hawa yang sejuk, hamparan tanaman hijau semakin memperkuat kekayaan alam Desa Keji. Tidak hanya potensi alam yang menjadi daya tarik desa ini, potensi budaya yang berkembang dalam wujud kesenian juga menjadi kekhasan tersendiri dari Desa Keji.

Pada awalnya potensi yang ada di Desa Keji ini belum dikembangkan untuk menjadi Desa Wisata. Namun berkat gagasan Bapak Yossiady Bambang Singgih PNS di Dinas Pariwisata Kabupaten Semarang potensi Desa Keji ini dikembangkan menjadi program paket wisata.Pengalaman menyaksikan kesenian, ritual dan merasakan kuliner masyarakat Desa Keji inilah yang memberikan inspirasi bagi Bapak Yossiady untuk membuat sebuah agenda pariwisata. Pada perkembangan awal, pariwisata Desa Keji ini orientasikan pada pengembangan potensi budaya yang ada.

Beberapa potensi budaya yang dikembangkan menjadi paket wisata antara lain: pertama, TariKuda Debog. Tarian ini merupakan inovasi dari tari kuda lumping di Desa Keji.Tari Kuda Debog berawal dari ide Bapak Yossiadyterkait dengan pengalaman masa kecilnya memainkan kuda mainan dari pelepah pisang. Inspirasi tarian dari pelepah pisang ini kemudian digarap dengan penuh artistic oleh Bapak Rajak Suharto sebagai pembina paguyuban Langen Budi Utomo sentra ide dan kreativitas budaya masyarakat. Tarian ini dijadikan sebagai ikon baru untuk menunjukkan keunikan dari tarian kuda lumping pada umumnya.Ide kreatif ini digagas oleh Bapak Rajak dan Bapak Yossiady agar ada daya tarik yang dapat mengundang wisatawan berkunjung ke Desa Keji kembali.

Kedua, mengemas makanan khas masyarakat desa menjadi wisata kuliner.Makanan khas di Desa Keji antaranya adalah pecel gablok dan gethuk tetek melek. Makanan tradisional tersebut kemudian disajikan saat wisatawan datang sebagai bagian dari welcome drink. Keduanya adalah makanan sehari-hari masyarakat Dusun Suruhan, yang masih ada dan sering dikonsumsi masyarakat sampai saat ini.Ketiga, Ritual Merti Dusun dan Ritual Iriban Banyu sebagai bentuk perwujudan rasa syukur masyarakat atas berlimpahnya rejeki yang diberikan oleh Sang Pencipta juga menjadi bagian yang dikemas menjadi kegiatan pariwisata. Ritual tersebut diselenggarakan dalam rangka memberi penghormatan kepada leluhur Dusun Suruhan yaitu Mbah Buyut Benah atau Mbah Klemu yang sering disebut sebagai danyang Dusun Suruhan.

Ketiga potensi itu kemudian dipaketkan ke dalam program wisata daerah yang bertajukOne Day Tour.Konsep tentang berliburke beberapa destinasi wisata dalam satu hari itu diprakarsai Disporpar Kabupaten Semarang pada tahun 2005. Konsep ini ditargetkan dapat meraup pangsa pasar wisatawan dari anak usia sekolah tingkat TK, SD, SMP, SMA dan wisatawan lanjut usia. Paket wisata semacam itu juga dapat 
menyesuaikan kebutuhan dan keinginan wisatawan yang beragam tersebut. Program One Day Toursebagai paket wisata yang ada di Desa Keji telah dijalankan sejak tahun 2006.Baru tanggal 26 Oktober 2008 Desa Keji khususnya Dusun Suruhan ditetapkan sebagai destinasi pariwisata olehWakil Bupati Kabupaten Semarang. Seiring dengan penetapan Desa Keji sebagai destinasi pariwisata dikembangkan pula konsep wisata seperti dolanan tradisional danoutbond.

\section{Konsep Desa Wisata Keji: Olahan Kawasan Konservasi Desa Jawa}

Desa wisata merupakan suatu kesatuan wilayah desa yang mempunyai kekayaaan sosial-budaya, dan alam yang sengaja dikemas untuk tujuan wisata. Kekayaan yang dimaksud diintergasikan dalam aktivitas kepariwisataan dengan berbagai fasilitas dan daya dukung untuk kegiatan kepariwisataan. Kekayaankekayaan yang tersebut merupakan tata cara dan pola kehidupan yang sudah terstruktur dalam masyarakat dan sesuai dengan tradisi masyarakat pendukung kebudayaan. Kepariwisataan yang ditawarkan dalam olahan desa wisata Jawa merupakan produk wisata desa yang mengedepankan kekayaan alam dan tradisi untuk tujuan wisata. Pun demikian yang terjadi pada masyarakat Desa Keji. Potensi sosial-budaya dan alam menjadi basis dalam pengembangan desa wisata olahan desa Jawa, yang meliputi potensi kuliner, dolanan, alam, dan kesenian yang ada di Desa Keji.

Bertolak dari potensi alam dan sosial budaya yang dimiliki oleh masyarakat Desa Keji yang sudah dijelaskan di atas, maka masyarakat mampu menyusun strategi untuk membentuk desanya sebagai salah satu arena wisata yang berbasis pada potensi desa Jawa. Wisata yang ditawarkan oleh masyarakat Desa Keji adalah wisata yang berbasis pada potensi lokal masyarakat Jawa, sehingga tidak salah apabila bentuk pariwisata yang disajikan dikatakan sebagai olahan kawasan konservasi desa wisata Jawa. Upaya yang dilakukan oleh masarakat Keji merupakan salah satu strategi untuk merevitalisasi sekaligus mengkonservasi kultur dan potensi daerah desa Jawa yang sempat terpinggirkan oleh kultur Barat dan global. Kegiatan semacam ini, selain mampu mempertahankan local wisdom masyarakat desa juga mampu meningkatkan pendapatan masyarakat Desa Keji. Hal ini bisa tercapai, karena masyarakat Keji tidak hanya diperlakukan sebagai objek wisata, tetapi masyarakat ditempatkan sebagai subjek atau pelaku utama dalam kegiatan kepariwisataan. Akibatnya, masyarakat mampu merasakan dampak langsung dari kegiatan pariwisata yang dilakukannya.

Desa dalam masyarakat Keji merupakan satu kesatuan sebagai arena kegiatan kepariwisataan. Kegiatan kepariwisataannya tersebar dalam satu kesatuan wilayah desa Keji. Sebab apa yang ditampilkan di Desa merupakan kemasan dan produk yang sengaja di jual kepada wisatawan, baik atraksi maupun pola kehidupan masyarakatnya. Jadi kegiatan masyarakat secara naturalpun bisa menjadi kegiatan yang bisa dinikmati para wisatawan yang berkunjung, baik wisatawan lokal maupun manca negara.

Desa Keji sebagai tempat kegiatan pariwisata sudah memenuhi kriteria sebagai konsep desa wisata yang berbasis pada kekayaan lokal masyarakat. Hal ini sesuai dengan pendapat Yaote (dalam Prasetyo, 2012) bahwa kegiatan pariwisata minimal mencakup tiga karakteristik utama, yaitu something to see, something to do, dan something to buy. Ketiga hal tersebut terinci sebagai berikut:

Something to see 
Sebagai tempat wisata yang berbasis kekayaan lokal, maka desa harus mampu menghadirkan produk yang bisa dinikmati oleh tourism dalam kegiatan parwisata. Desa Keji sebagai desa wisata memiliki sajian yang dapat dinikmati (lihat) oleh para wisatawan. Beberapa produk tu seperti, permainan 'tradisional' anak-anak, panorama sajian wisata yang kental dengan suasana desa, dan kesenian masyarakat Desa Keji.

Something to do

Kegiatan wisata dewasa ini tidak hanya memperlakukan wisatawan sebagai wisatawan yang pasif atau hanya sekedar menikmati sajian yang ditawarkan oleh produk tempat dimana kegiatan tersebut dilakukan kegiatan wisata. Dalam kegiatan ini wisatawan bisa ikut serta melakukan kegiatan yang dilakukan masyarakat sebagai sajian wisata. Jadi wisatawan tidak hanya sekedar melihat, tetapi juga bisa menjadi pelaku sendiri. Dalam kontek lebih jauh, bagaimana wisatawan dibuat lebih nyaman dengan sajian wisata, sehingga wisatawan betah berlama-lama di desa wisata. Untuk hal ini, masyarakat bahkan menyediakan fasilitas homestay yang bernuansa desa. Misal, permainan 'tradisional' egrang, dakon, dan ikut tarian-anak-anak, homestay.

\section{Something to buy}

Maksudnya kegiatan pariwisata harus mampu memberikan fasilitas atau menyediakan barang-barang yang bisa dibeli oleh para wisatawan yang berkunjung. Beberapa produk yang bisa dibeli oleh wisatawan yang berkunjung ke desa Keji adalah kuliner lokal masyarakat Desa Keji.

Adapun paket wisata yang ditawarkan oleh masyarakat Desa Keji dalam mewujudkan desanya sebagai desa wisata yang ada di Ungaran Barat, yaitu:

\section{Paket Edukatif}

Jenis paket petama ini didesain untuk kegiatan pendidikan yang berusaha untuk mengenalkan kultur masyarakat Keji kepada para wisatawan. Kegiatan yang bisa menjadi paket eduwisata dalam kepariwisataan masyarakat desa di Keji adalah mengajarkan kepada para wisatawan untuk belajar membatik khas desa Keji, yaitu batik dengan motif kuda debog-bunga terompet dan srengenge, serta pengenalan wayang punakawan.

\section{Paket One Day}

Paket one day yang ditawarkan oleh Desa Keji merupakan paket kedua yang digunakan oleh inovator dalam mengenalkan dan mengembangkan desa wisata. Pihak fasilitator akan memberikan antar jemput dalam kegiatan wisata baik yang ada di Keji maupun dihantarkan ke wisata lain yang ada di Semarang, misal dalam perjalanan pulang wisatwan diajak berkeliling di Kota Semarang dan wisata belanja khas yang ada di Semarang. Paket kedua ini merupakan upaya masyarakat Desa Keji untuk mempromosikan dan mengenalkan wisata yang ada di Desa Keji.

\section{Kesadaran dan Partisipasi Masyarakat dalam Membangun WisataLokal}

Partisipasi merupakan istilah diskriptif yang menunjukan keterlibatan beberapa orang dengan jumlah signifikan dalam berbagai situasi atau tindakan yang dapat meningkatkan kesejahteraan hidup mereka (Nasution, 2009). Dalam kaitanya dengan pariwisata, partisipasi masyarakat adalah peran seorang atau kelompok untuk terlibat dalam memanfaatkan potensi objek wisata, dimana seseorang berpartisipasi 
berarti dia berperan atau terlibat dalam kegiatan-kegiatan yang dilakukannya dengan kemauan sendiri tanpa paksaan dari pihak lain.

Berdasarkan penelitian yang penulis lakukan sistim pembangunan desa wisata keji ini menggunakan sistem pembangunan yang bersifat bottom up yaitu masyarakat setempat ikut terlibat dalam pemilihan, perancangan, perencanaan dan pelaksanaan program kebijakan yang akan mewarnai kehidupan mereka, sehingga dapat dijamin bahwa persepsi masyarakat setempat, pola sikap dan pola berpikir, serta nilai-nilai dan pengetahuanya ikut dipertimbangkan secara penuh.

Asumsi tersebut diperkuat dengan adanya data yang penulis dapatkan, dimana masyarakat sebagai agen, melakukan beberapa aksi/tindakan sosial berupa pelestarian kesenian dan adat yang ada di Dusun Suruhan. Pelestarian tersebut ditunjukkan oleh Paguyuban Langen Budi Utomo yang menampung kesenian tari Kuda Lumping dan menjadi penggerak masyarakat pada saat Dusun Suruhan, Desa Keji melakukan kegiatan rutin seperti Ritual Merti Dusun dan Ritual Iriban Banyu.

Rutinitas di Dusun Suruhan, Desa Keji dalam kurun waktu 44 tahun, yaitu mengajarkan tari Kuda Lumping dan melestarikan Ritual Merti Dusun serta Ritual Iriban Banyu. Kegiatan pelestarian telah dijalankan dari generasi ke generasi, semenjak tahun 1971 hingga sekarang tahun 2015. Pelestarian ini berkaitan dengan pariwisata yang mulai direncanakan pada tahun 2006 yang melibatkan kearifan lokal Dusun Suruhan, Desa Keji.

Penetapan Dusun Suruhan, Desa Keji sebagai destinasi pariwisata memengaruhi kegiatan pelatihan tari, terutama pada tahun 2006-2012 hampir setiap minggu pelatihan tari diadakan sebagai bentuk persiapan pentas saat penyambutan wisatawan. Pentas untuk pariwisata menggunakan tari Kuda Debog sebagai ikon utama di Dusun Suruhan, hasil inovasi dan kolaborasi Bapak Rajak dengan Bapak Yossiady.

Pemerintah mulai melakukan upaya untuk pengembangan wisata di Dusun Suruhan, Desa Keji salah satunya dengan upaya bersama mengambil peran dalam program pengembangan Desa Kejimenjadi Desa Wisata. Masyarakat sebagai pelaku wisata dan pemerintah sebagai fasilitator serta motivator. Upaya pelatihan yang menjadi perjumpaan sosial secara rutin, akan terbentuk suatu aksi/ tindakan berdasarkan interaksi yang terjalin antara pihak pemerintah dan masyarakat.

Pembangunan pengetahuan masyarakat mengenai kondisi lingkungan sekitar tempat tinggal dan ketentuan secara adat mengenai pelaksanaan ritual digunakan untuk memahami proses pengembangan Dusun Suruhan, Desa Keji sebagai destinasi wisata. Pemanfaatannya dapat melalui proses pelatihan-pelatihan mengenai pariwisata untuk mengembangkan potensi sesuai dengan pengetahuan yang dimiliki masyarakat. Pelatihan yang telah dilakukan berkaitan dengan pengembangan pariwisata antara lain adalah pelatihan pembuatan kuliner. Pelatihan pembuatan kuliner berupa pengemasan produk yang menarik sesuai dengan kuliner khas Dusun Suruhan.

Proses pelatihan yang dilakukan mengandung tujuan sebagai sosialisai untuk memberikan pemahaman dan pengertian kepada masyarakat mengenai pengembangan pariwisata. Sosialisasi yang diterapkan bersama pelatihan akan memudahkan masyarakat mengerti posisinya sebagai agen untuk memahami keberadaan dan kegiatan pariwisata di daerahnya. Agen berhak mengadakan musyawarah dengan beberapa pihak mengenai perkembangan pariwisata. Pihak yang 
terlibat antaralain, tokoh masyarakat, pengelola pariwisata dan pihak pemerintahan desa.

Legitimasi dalam penelitian ini adalah ketetapan mengenai pelaksanaan wisata berdasarkan kearifan lokal yang ada di Dusun Suruhan. Kearifan lokal tersebut dapat berupa tampilan kesenian tari dan gambaran mengenai ritual-ritual yang diadakan di Dusun Suruhan. Legitimasi yang ada di dalam masyarakat sebagai agen dalam pariwisata adalah berperan dalam membentuk dan mengembangkan Dusun Suruhan, Desa Keji sebagai destinasi wisata. Pengembangan ditunjukan dengan terciptanya tari Kuda Debog yang merupakan jenis tari kreasi untuk kepentingan pariwisata.

Peran masyarakat Dusun Suruhan, Desa Keji juga dipengaruhi oleh tingkat kesadaran, diantaranya motivasi tak sadar, kesadaran praktis dan kesadaran diskursif. Pada penelitian ini motivasi tak sadar yang ditunjukan oleh masyarakat Dusun Suruhan, Desa Keji sebagai agen untuk menjaga dan mengembangkan wisata dengan berbasis kearifan lokal yang ada di Dusun Suruhan, namun alasan sebenarnya adalah untuk mendapatkan uang. Motivasi untuk mendapatkan uang merupakan salah satu kepentingan yang mengarahkan menjadi aktor dalam pariwisata

Pada penelitian ini masyarakat menjelaskan alasan berperan dalam program pengembangan pariwisata di Dusun Suruhan, Desa Keji untuk menjadikan desanya lebih maju dan ramai dikunjungi. Masyarakat merasa saat ramai wisatawan yang datang, maka banyak kegiatan yang dilakukan dan banyak pengalaman yang mereka dapatkan.

Penggunaan rutinitas dan kesadaran praktis dalam pembentukan Desa wisata di Dusun Suruhan, Desa Keji adalah kegiatan masyarakat yang dilakukan secara rutin dan berulang.Masyarakat dengan rutinitasnya, telah menganggap pariwisata sebagai bagian dalam kegiatan sehari-hari mereka. Pariwisata berjalan dengan teratur, diawali dengan wisatawan yang datang setiap minggu berkat bantuan Bapak Yossi. Pementasan seni tari oleh Paguyuban Langen Budi Utomo, permainan outbond dan edukasi yang dilakukan oleh pemilik home industri serta pelaksanaan home stay yang melibatkan masyarakat secara umum.

\section{Pelayanan dan Pengelolaan Wisata terhadap Tourism di Desa Keji}

Desa Keji sebagai desa tujuan wisata terus meningkatkan pelayanan dan pengelolaan wisata secara lebih baik. Pada tahun 2012 Desa Keji mendapat dukungan dana yang dialokasikan untuk pengembangan SDM dan pembangunan fisik sarana penunjang wisata. Kegiatan yang dilakukan dalam rangka pengembangan SDM berupa pelatihan tari danmemainkan gamelan untuk anak-anak, pelatihan ibu-ibu untuk mengembangkan wisata kulinernya, pelatihan bagi pengelola outbond dan pelatihan bagi perangkat desa agar melek teknologi informasi. Upaya tersebut dilakukan agar dapat meningkatkan kesadaran dan pengetahuan masyarakat untuk lebih proaktif memajukan pengembangan desa wisata.Sedangkan pengembangan fisik diorientasikan pada pembangunan fisik sarana prasarana kegiatan pariwisata.Pada tahun 2012 Desa Keji telah memiliki fasilitas homestay yang diperuntukan bagi wisatawan yang ingin merasakan bermalam di Desa Keji.Pembangunan sarana fisik yang mempermudah akses wisata belum sepenuhnya berkembang sebagaimana yang diharapkan, sebab akses masuk ke desa masih belum dapat dilalui kendaraan besar.

Wisata Desa Keji ini dikelola oleh Bapak Yossiady pada periode tahun 2006 2013.Banyak hal yang telah diupayakan oleh Bapak Yossiady dalam mengmbangkan 
Desa Keji sebagai desa wisata.Pada tahun 2006 awal berdirinya Desa keji sebagai desa wisata, wisatawan yang berkunjung dapat menikmati paket wisata ke beberapa tempat destinasi wisata yang dipusatkan di Dusun Suruhan.Adanya penetapan Desa Keji sebagai destinasi wisata, pengelola banyak melakukan pembenahan juga inovasi kegiatan pariwisata.Paket wisata yang ditawarkan semakin beragam disesuaikan dengan kebutuhan dan keinginan wisatawan.Akan tetapi paket wisata yang beragram tersebut juga berpengaruh terhadap biaya yang dikeluarkan wisatawan.

Paket tambahan kegiatan yang berpengaruh pada jumlah biaya yang dikeluarkan wisatawan antaralain untuk kegiatan outbond, kegiatan susur sungai dan kegiatan ke home industri. Masyarakat yang terlibat dalam pengembangan wisata seperti pemilik home industriyang menjadi salah satu tujuan kunjungan wisatawan dapat merasakan hasil kunjungan wisata tersebut. Ada penambahan pendapatan yang diterima pemilik home industri tersebut karena telah ikut serta dalam praktek dan menjelaskan kepada wisatawan mengenai kegiatan home industri. Kegiatan outbound yang dikembangkan oleh pengelola dapat menerima wisatawan baik secara individu maupun berkelompok seperti misalnya anak sekolah, karyawan atau pegawai. Bagi wisatawan yang ingin menikmati outbond biayanya dihitung dari seberapa banyak jumlah kegiatan outbond yang diikuti.

Pengelolaan paket wisata Desa Keji yang terkait dengan kesenian dilakukan melalui paguyuban Langen Budi Utomo yang dibina oleh Bapak Rajak. Sedangkan paket kunjungan home industridikelola oleh masing-masing pemilik home industri itu sendiri, namun demikian berjalannya home industriitu terintegrasi dengan wisata. Home industri yang terdapat di Desa Keji antara lain memprodusksitempe, jamu dan susu. Pada kegiatan kunjungan ke home industri wisatawan diajak ikut merasakan bagaimana cara membuat tempe, membuat jamu dan susu. Sedangkan paket outbound dikelola oleh para guide outbound yang telah terlatih untuk memandu wisatawan melakukan kegiatan tersebut.

\section{Analisis SWOT terhadap “Olahan Kawasan Konservasi" Desa Wisata Jawa untuk Mewujudkan Masyarakat Sadar Wisata Berbasis Potensi Lokal pada Masyarakat Keji, Ungaran Barat}

Era otonomi daerah yang diberlakukan di Indonesia menjadi ajang pemunculan kreativitas dan penguatan potensi lokal di berbagai daerah. Berbagai kreativitas tersebut muncul untuk meningkatkan ekonomi masyarakat lokal. Konsekuensi otonomi tersebut berdampak pada munculnya kekhasan yang dikemas oleh setiap daerah dalam menampilkan kekayaan daerah. Fenomena ini bermunculan di setiap masyarakat baik sebagai icon utama maupun sebagai pendukung kekayaan lokal yang sudah ada sebelumnya. Kebanyakan fenomena tersebut terjadi pada sektor industri pariwisata, baik pariwisata religi, alam, dan seni-budaya. Banyaknya minat masyarakat untuk melakukan kunjungan wisata menjadi tantangan di setiap daerah untuk mengenalkan kekayaan lokalnya lewat kemasan industri wisatawa. Pun demikian yang terjadi pada masyarakat Desa Keji, di Ungaran Barat, Semarang.

Desa wisata yang adai Desa Keji, Ungaran Barat tergolong desa wisata yan berbasis pada kekayaan lokal. Tidak mengherankan apabila masyarakat menyebutnya sebagai wisata yang menjual kekayaan lokal yang ada dalam masyarakat desa. Kekayaan lokal tersebut mencakup kekayaan berupa nilai-nilai yang terdapat pada permainan tradisional, kuliner, alam, serta arsitektur rumah yang bernuansa 
masyarakat desa. Kekayaan lokal tersebut di desain sedemikian rupa, sehingga sangat menarik untuk dikunjungi. Masyarakat Desa Keji sudah sadar akan potensi kekayaan desanya. Kesadaran yang terbentuk dari masyarakat terkoordinir dan terlahirlah konsep desa wisata berbasis pada kekayaan lokal.

Kekuatan Olahan Desa Wisata Keji: Keji sebagai desa wisata Jawa sengaja dibentuk dengan menggunakan pendekatan berbasis pada potensi rakyat dan lingkungan alam khas desa Jawa. Banyak potensi yang bisa dikembangkan dari potensi yang dimiliki oleh masyarakat Desa Keji. Diantara potensi tersebut, yaitu potensi SDM, seni-tradisi, alam, kuliner, dan home stay khas rumah Jawa. Keunikan yang dimiliki oleh desa menjadi daya tarik bagi masyarakat untuk bernostalgia menikmati panorama desa yang selama ini sudah mulai tergempur oleh budaya barat dan modern. Kebanyakan masyarakat desa akan dibangun dan dikembangkan dengan mengadopsi masyarakat kota. Pendekatan yang beroarientsi pada maksimalisasi tanpa memperhatikan budaya dan kekuatan lokal hanya akan menciptakan kekerasan budaya bagi masyarakat yang sedang dibangun. Banyaknya pembangunan yang sudah dilakukan di Indonesia yang tidak menggunakan pendekatan buttom up akan bermuara pada kegagalan dari program pembangunan. Arah pembangunan yang hanya sekedar proyek akan mengakibatkan munculnya resistensi dari masyarakat sasaran. Berkaca dari kasus tersebut, maka sudah mulai ada kesadaran dari masyarakat daerah bahwa pembangunan harus beroerientasi pada penciptaan pemenuhan kebutuhan dan penyelesaian masalah. Dengan kesadaran SDM yang ada, maka akan mewujudkan pembangunan masyarakat yang bertumpu pada partisipasi masyarakat. Partisipasi yang masyarakat yang dulu jarang dilakukan, kini menjadi suatu keharusan dalam pengembangan yang dilakukan oleh masyarakat desa. Kesadaran masyarakat dalam mewujudkan desanya sebagai desa wisata menjadi kekuatan tersendiri dalam membangun masyarakat dari kebutuhan masyarakat.

Kelemahan Menciptakan Ruang Wisata Desa Jawa: menciptakan desa sebagai desa wisata yang berbasis pada potensi yang dimiliki khas desa bukan sama sekali tidak melakukan inovasi yang sedang diminati oleh wisatawan lokal dan mancanegara. Kurangnya kesadaran masyarakat dan pengelola terhadap menciptakan inovasi dalam melakukan revitalisasi untuk membentuk desa wisata terjadi dalam hal ini. Orientasi maksimalisasi dalam hal ekonomi terlalu kuat mengakibatkan konsentrasi pada penguatan dan inovasi kurang dilakukan. Hal ini menjadi penting karena kegiatan wisata saat ini bukan hanya kegiatan melihat, tetapi juga aktivitas yang melibatkan wisatawan langsung dalam kegiatan pariwisata. Kegiatan pemetaan dan revitalisasi yang dilakukan oleh masyarakat Keji masih terbatas pada memunculkan untuk kegiatan ritual. Kelemahan yang terjadi diakibatkan kurang adanya pendampingan yang dilakukan oleh pemerintah/fasilitator yang benar-benar paham akan kepariwisataan. Kegiatan pariwisata bukan hanya orientasi wisata untuk maksimalisasi, tetapi juga digunakan untuk model saluran mereproduksi dan merekonstruksi kultur dan lingkungan masyarakat sebagai penyangga wisata lokal. Gerakan dari bawah dengan berdasarkan masalah dan kebutuhan dalam memunculkan daerah wisata baru sangat diperlukan, tetapi dukungan pemerintah dalam bentuk fasilitasi tidak bisa diabaikan. Kurang hadirnya atau dominannya fasilitasi dalam mewujudkan desa wisata merupakan dinamika masalah intern dalam membentuk desa wisata. Selain itu, masyarakat di sekitar perlu digerakkan dan dilibatkan untuk mendukung kegiatan kepariwisataan. Saat ini Keji kurang melibatkan 
masyarakat di sekitarnya untuk menciptakan desa wisata. Relasi sosial dan solidaritas antara masyarakat kurang dimuncukan sebagai modal untuk menciptakan wisata desa yang berkesinambungan.

Peluang Desa Wisata Berbasis Potensi Lokal: banyaknya masyarakat melakukan kegiatan wisata menjadi landasan terhadap hadirnya kondep dan model desa wisata sebagai hasil olahan potensi lokal yang dikembangkan oleh Desa Keji. Revitalisasi potensi yang ada di Keji menjadi keharusan untuk dilakukan. Revitalisasi bukan hanya sekedar hadir kembali, tetapi harus mampu menciptakan inovasi baru yang bisa membaca keinginan para wisatawan. Minat wisatawan bukan hanya untuk dipenuhi, tetapi harus ditawarkan dengan produk-produk baru hasil kombinasi antara yang tradisional sebagai representasi desa dan modern sebagai representasi kota. Selain itu, untuk membuat Desa Keji sebagai desa wisata Jawa yang berkesinambungan harus mampu menguatkan peluang-peluang yang bisa dikembangkan, diantaranya yaitu sebagai berikut:

a. Banyak investor yang dapat berperan sebagai mitra dalam membangun desa wisata di Keji

b. Perkembangan teknologi informasi dan komunikasi yang semakin pesat sebagai salah satu media promosi

c. Kebijakan pemerintah yang mendukung pendidikan kegiatan masyarakat lokal dalam mengembangkan kepariwisataan daerah

d. Konsep back to nature atau mempertahankan budaya lokal yang ada di masyarakat Keji

e. Banyaknya pemuda yang bisa diajak membangun desa wisata

f. Melakukan inovasi dalam stragei pemasaran dan bonus terhadap wisatawan baik wisatawan lokal maupun manca negara.

Ancaman terhadap Desa Keji sebagai Olahan Desa Wisata Berbasis

Konservasi: hadirnya pasar modern yang dikemas menjadi salah satu kegiatan wisata menjadi salah satu ancaman bagi keberadaan pariwisata daerah. Pasar modern yang selalu melakukan inovasi dan diskon menjadikan masyarkat pelaku wisatawan menjadi teralihkan untuk melakukan kunjungan wisata yang berbasis masyarakat desa. Tidak sepahamnya masyarakat desa dan pengelola seni menjadi ancaman terhadap keberlangsungan wisata yang dibentuk oleh masyarakat Desa Keji. Berdasarkan pengakuan masyarakat bahwa wisata yang berusaha memadukan berbagai potensi dalam satu wadah wisata desa telah menimbulkan kress. Menurut Bapak Juwarno, pihak sanggar telah melakukan sembarang perekrutan pemain seni. Jadi apa yang disajikan kepada wisatawan tersesan asal, tidak mengahdirkan essensi dari nilai seni yang disampaikan ke pengunjung.

Berikut merupakan ancaman terhadap kegiatan wisata di Keji, selain apa yang sudah dideskripsikan di atas:

1. Lunturnya budaya lokal apabila tidak ditangani secara tepat

2. Konflik dengan masyarakat lokal apabila pendekatannya kurang tepat

3. Fasilitas dan perangkat pembelajaran yang belum ada

4. Belum adanya regulasi dan dana yang memadai

5. Membutuhkan tim pemantau yang paham akan program

6. Kepentingan lembaga tidak sejalan dengan kebutuhan rakyat 
7. Masyarakat yang tinggal di sekitar kegiatan wisata kurang dilibatkan untuk kegiatan dan penguatan kepariwisataan

Berdasarkan kekuatan, kelemahan, kesempatan, dan ancaman yang sudah dideskripsikan, maka bisa dibuat startegi rumusan pengembangan berdasarkan keadaan tersebut, yaitu:

Matriks 1. Rumusan Strategi Pengembangan Olahan Desa Wisata Berbasis Konservasi Desa yang Bertumpu pada Masyarakat Lokal dengan Kajian Antropologis Berdasarkan Model SWOT

\begin{tabular}{|c|c|c|}
\hline Faktor Eksternal & $\begin{array}{l}\text { S: Strength } \\
\text { 1.Dukungan sumberdaya } \\
\text { manusia yang sangat kuat } \\
\text { dalam memegang adat } \\
\text { istiadat peninggalan } \\
\text { leluhurnya } \\
\text { 2. Adanya ruang kesadaran } \\
\text { masyarakat lokal dalam } \\
\text { memunculkan kegiatan } \\
\text { wisata di desa } \\
\text { 3.Lokasi dan potensi alam } \\
\text { dengan karakteristik } \\
\text { bentang alam yang khas } \\
\text { 4.Salah satu Pioneer dalam } \\
\text { melahirkan desa wisata } \\
\text { konservasi di Semarang } \\
\text { berbasis pada masyarakat } \\
\text { lokal } \\
\text { 5. Banyak peneliti dan } \\
\text { antropolog berkualitas } \\
\text { yang dimiliki oleh } \\
\text { Indonesia } \\
\text { 6.Salah satu cara saluran } \\
\text { revitalisasi kultur } \\
\text { masyarakat lewat saluran } \\
\text { kepariwisataan yang } \\
\text { bertumpu pada aset lokal }\end{array}$ & $\begin{array}{l}\text { W: Weakness } \\
\text { 1. Kurang pahamnya } \\
\text { masyarakat lokal dalam } \\
\text { mengidentifikasi aset yang } \\
\text { bisa dikemas dalam industri } \\
\text { wisata desa } \\
\text { 2. Sistem manajemen yang } \\
\text { masih masih berorientasi } \\
\text { pada perbaikan (mengobati) } \\
\text { dari pada mencegah } \\
\text { 3. Pola kebijakan yang masih } \\
\text { top down } \\
\text { 4. Kurang melibatkan } \\
\text { masyarakat sekitar sebagai } \\
\text { daya dukung kegiatan } \\
\text { wisata desa }\end{array}$ \\
\hline $\begin{array}{l}\text { O: Opportunity } \\
\text { 1. Banyak investor yang } \\
\text { dapat berperan } \\
\text { sebagai mitra dalam } \\
\text { membangun desa } \\
\text { wisata di Keji } \\
\text { 2. Perkembangan } \\
\text { teknologi informasi } \\
\text { dan komunikasi yang } \\
\text { semakin pesat } \\
\text { sebagai salah satu }\end{array}$ & $\begin{array}{l}\text { Strategi S-O } \\
\text { 1.Membuat variasi pola } \\
\text { pemberdayaan masyarakat } \\
\text { untuk merevitalisasi aset- } \\
\text { aset lokal yang bisa } \\
\text { dikemas dalam kegiatan } \\
\text { kepariwisataan dengan } \\
\text { pendekatan emik dan etik } \\
\text { 2.Menggunakan kearifan } \\
\text { lokal dan pendidikan akan } \\
\text { kesadaran serta parsisipasi }\end{array}$ & $\begin{array}{l}\text { Strategi W-O } \\
\text { 1. Menetapkan pola yang jelas } \\
\text { berdasarkan kearifan lokal } \\
\text { 2. Meningkatkan kualitas dan } \\
\text { kuantitas pengelola yang } \\
\text { ditunjuk sebagai } \\
\text { pendamping kegiatan } \\
\text { 3. Terakomodasinya kearifan } \\
\text { lokal dan keunggulan lokal } \\
\text { 4. Membuka kerjasama dengan } \\
\text { mitra untuk }\end{array}$ \\
\hline
\end{tabular}


media promosi

3. Kebijakan pemerintah yang mendukung pendidikan kegiatan masyarakat lokal dalam mengembangkan kepariwisataan daerah

4. Konsep back to nature atau mempertahankan budaya lokal yang ada di masyarakat Keji

5. Banyaknya pemuda yang bisa diajak membangun desa wisata

\section{T:Threats}

1. Lunturnya budaya lokal apabila tidak ditangani secara tepat

2. Konflik dengan masyarakat lokal apabila pendekatannya kurang tepat

3. Fasilitas dan perangkat pembelajaran yang belum ada

4. Belum adanya regulasi dan dana yang memadai

5. Membutuhkan tim pemantau yang paham akan program

6. Kepentingan lembaga tidak sejalan dengan kebutuhan rakyat

7. Masyarakat yang tinggal di sekitar kegiatan wisata kurang dilibatkan untuk kegiatan dan masyarakat lewat forumforum dalam masyarakat dengan berbagai kegiatan

3.Memperkecil resiko akibat adanya kegiatan kepariwisataan yang kemungkinan akan dikunjungi oleh wisatawan lokal dan mancanegara

4.Menciptakan ruang kepada wisatwan untuk bernostalgia lewat wisata konservasi desa mengembangkan kegiatan pariwisata yang sudah ada

5. Mengadakan evaluasi terhadap berjalannya kegiatan wisata untuk menyusun strategi baru dalam menarik wisatawa lokal dan manca negara

6. Menciptakan pola wisata edukatif dari kegiatan wisata di desa Keji

\section{Strategi S-T}

1. Konsep strategi dan pemeliharaan kearifan lokal

2. Menyediakan kemungkinankemungkinan diperlukan yang mengatasi masalah yang muncul akibat kegiatan pariwisata sejak dini sebagai alternatif solusi

\section{Strategi W-T}

1. Membuat pemahaman dan kebijakan yang tepat dengan budaya lokal masyarakat sekitar yang kemudian dikemas ke dalam model pendidkan yang berkesinambungan untuk kegiatan pariwisata desa Keji

2. Di sekolah membuat pengintegrasian muatan lokal dan ekstrakurikuler di berbagai kegiatan lainnya; serta di masyarakat diintegrasikan dengan berbagai kegiatan masyarakat seperti pada perkumpulan masyarakat secara berkesinambungan

\section{Menemukan tenaga} yang paham untuk pengembangan wisata desa berkelanjutan 
penguatan

kepariwisataan

Rumusan di atas merupakan deskripsi kenyataan atas realitas yang terjadi pada fenomena desa wisata Keji, Ungaran Barat. Rumusan yang terwacanakan merupakan strategi alternatif dalam menguatkan kesadaran dan inovasi dalam melakukan revitalisasi budaya khas Jawa untuk menarik wisatawan berkunjung ke Desa Keji di era global yang serba modern.

\section{PENUTUP}

Olahan desa wisata yang berbasis konsrvasi pada masyarakat Desa keji mempunyai potensi yang berbada dengan kegiatan wisata yang ada di Indonesia. Wisata yang ditawarkan oleh Desa Keji adalah hasil reproduksi sosial-kultur dan alam yang dikombinasi dengan kebutuhan para wisatawan baik lokal maupun manca negara. Dalam mewujudkan Desa Keji sebagai salah satu pusat wisata yang menjual kekhasan desa secra berkelanjutan, masyarakat Keji telah melakukan berbagai strategi, termasuk membangun partisipi masyarakat Desa Keji. Partisipasi yang dilakukan oleh masyaraat masih terbatas pada partisipasi manipulatif yang dilakukan oleh pengelola. Hal ini terbukti ketika memadukan berbagai potensi dalam aktvitas dan serangkaian wisata khas desa masih terkesan tidak dikomunikasikan. Partisipasi masih tidak mencapai satu kesepahaman dalam mewujudkan Desa keji sebagai desa wisata. Salah satu indkatornya yaitu terjadinya konflik intern antara pengeola, masyarakat, dan sanggar seni yang ada di Desa Keji. Pun demikian dengan sistem pengelolaan terhadap potensi dan pemasaran yang dilakukan untuk mengenalkan ke dunia luar masih mengalami masalah. Masalah yang terjadi karena masyarakat terlalu tergesagesa untuk memperoleh keuntungan maksimal secara ekonomi. Orientasi yang demikian membuat masyarakat terlena, bahwa sebenarnya yang ingin ditawarkan oleh masyarakat Keji terhadap wisatawan adalah kultur masyarakat desa yang terkemas dalam industri wisata.

Bagi masyarakat lokal hendaknya tidak hanya berorintasi pada maksimalisasi ekonomi, tetapi harus mampu menumbuhkan ruang kesadaran untuk melakukan reproduksi sosial-kultur. Kehadiran peluang ini harapannya digunakan masyarakat Desa Keji untuk memunculkan potensi desa yang dikombinasi dan diinovasikan untuk menjawab tantatangan kebutuhan para wisatwan. Kesempatan ini juga harus digunakan untuk memperkuat solidaritas dalam masyarakat dan masyarakat di sekitar Desa Keji sebagai kekuatan masyarakat desa. Hal ini dilakukan dengan memanfaatkan modal sosial agar dalam membentuk wisata desa yang berkelanjutan bisa tercapai.

Bagi fasilitator dan pemerintah diharapkan bersinergi dengan masalah dan apa yang diinginkan oleh masyarakat yang akan dikembang menjadi desa olahan desa wisata konservasi berbasi potensi lokal desa.

\section{REFERENSI}

Anonim. Tt.http://www.p2par.itb.ac.id/?page_id=747. 'Studi Pengembangan Model Pariwisata Perdesaan'. 
Indrawati, Nindi. 2015. Peran Masyarakat dalam Pengembangan Pariwisata Berbasis Kearifan Lokal di Dusun Suruhan Desa Keji Ungaran Barat Kabupaten Semarang. Skripsi. Semarang: Jurusan Sosiologi dan Antropologi, FIS, UNNES.

Ketjulan, Romy. 2010. Analisis Kesesuain dan Daya Dukung Ekowisata Bahari Pulau Hari Kecamatan Laonti Kabupaten Konawe Selatan Provinsi Sulawesi Tenggara. Bogor: IPB.

Miles, B Matthew \& A. Michael Huberman. 1992. Analisis Data kualitatif. Terjemahan Tjetjep Rohendi Rohidi. Edisi Pertama. Jakarta: UI Press.

Mustofa, dkk. 2013. Pengembangan Model Wisata Pendidikan (Eduwisata) Berbasis Konservasi Tanaman Porang di Universitas Negeri Semarang dalam Mendukung Pemberdayaan Masyarakat. Laporan Penelitian Universitas Negeri Semarang.

Palevi, Reza. 2015. Eksistensi Kesenian Jaran Kepang dalam Arus Industri Pariwisata di Dusun Suruhan Desa Keji Kabupaten Semarang.Skripsi. Semarang: Jurusan Sosiologi dan Antropologi, FIS, UNNES.

Pitana, I Gede dan Putu G. Gayatri. 2005. Sosiologi Pariwisata.Yogyakarta:ANDI.

Presetyo, Antonius Seno Hari. 2012. Perancangan Desa Wisata Kebonagung. Skripsi. Jogjakarta: Program Studi Arsitektur, Fakutasl Teknik Universitas Atma Jaya Yogyakarta.

Rachman, Maman. 1999. Strategi dan Langkah-Langkah Penelitian. Semarang: IKIP Semarang Press.

Satria, Arif. 2009. Pesisir dan Laut untuk Rakyat. Bogor: IPB Press.

Schensul, S.L. Schensul J.J. \& LeCompte, M.D. 1999. Essential Ethnographic Methods:Observations, Interviews, and Questionnaires. California: AltaMira Press.

Suminarto. 2012. Dalam http://budisuminarto.blogspot.com/2012/11/desawisata.html. 